\title{
Building and Cost Analysis of an Industrial Automation System using Industrial Robots and PLC Integration*
}

\author{
Enes Efe ${ }^{1 \dagger}$, Muciz Ozcan ${ }^{2}$, Huseyin Hakli ${ }^{3}$ \\ ${ }^{1 *}$ Hitit University, Department of Electrical and Electronics Engineering,Corum, Turkey, (ORCID ID 0000-0002-6136-6140), enesefe@hitit.edu.tr \\ ${ }^{2}$ Necmettin Erbakan University, Department of EEE, Konya, Turkey, (ORCID ID 0000-0001-5277-6650) mozcan@erbakan.edu.tr \\ ${ }^{3}$ Necmettin Erbakan Univertsity, Department of Computer Engineering, Konya, Turkey, (ORCID ID 0000-0001-5019-071X) hhakli@erbakan.edu.tr
}

(1st International Conference on Applied Engineering and Natural Sciences ICAENS 2021, November 1-3, 2021)

(DOI: 10.31590/ejosat.972290)

ATIF/REFERENCE: Efe, E., Ozcan, M. \& Hakl, H. (2021). Building and Cost Analysis of an Industrial Automation System using Industrial Robots and Programmable Logic Controller Integration. European Journal of Science and Technology, (28), 1-10.

\begin{abstract}
Technology rapidly advances on a daily basis and the resulting changes can provide numerousbenefits for manufacturing methods and machines. Manufacturers who are able to swiftly embrace thesedevelopments can increase their manufacturing output, thereby boosting profitability and gainingcompetitive advantages over their rivals. However, the cost savings which result from new innovationscan vary, depending on the manufacturing model. Consequently, manufacturers need to conduct accurateanalyses for appropriate manufacturing methods in order to ensure that new changes are cost-effective.Nowadays, the use of industrial automation systems is gaining popularity as a method of increasingprofitability for mass production, and these systems utilize control systems, such as industrial robots andprogrammable logic controllers. The use of these elements in the manufacturing process not onlyprovides quality and flexible production methods, which are indispensable considerations, but alsoconserves human effort. The aim of this study was to minimize the cost of a factory-installed industrialautomation system, which produced globe valves with side couplings, through the combined use ofindustrial robots and programmable logic controllers. While calculating returns from the installed system,the differential evolution algorithm was used to predict future unit prices of electricity, and it wasdetermined that the cost of investment would be recovered after a maximum of 2.5 years and that currentyearly production would increase fourfold.
\end{abstract}

Keywords: Industrial automation, Programmable logic controller, Industrial robots, Differential evolution algorithm, Prediction.

\section{Endüstriyel Robot ve PLC Entegrasyonuyla Talaşlı İmalat Üretim İşleminin Gerçekleştirilmesi}

$\ddot{\mathbf{O} z}$

Üreticiler üretim şekillerini değiştirmeden önce doğru analizler yaparak kendilerine en uygun üretim yöntemini seçmeleri gerekmektedir. Bu çalışmada yan rakorlu küresel vana üretilen bir fabrikada Endüstriyel Otomasyon Sistemi kurulmuş ve kurulan bu sistemin maliyeti Endüstriyel Robot ve PLC beraber kullanılarak en aza indirilmesi hedeflenmiştir. Üretim yönteminde Endüstriyel Robotun kullanılması ve mevcut sistemde ki üretimde bir takım değişiklikler yapılmasıyla esnek üretim sağlanmış ve üretimin aksamaması için bazı tedbirler alınmıştır. Kurulan sistem maliyetinin geri dönüşüm süreci hesaplanmasında Diferansiyel Evrim Algoritmasından yararlanılarak gelecekteki elektrik birim fiyatları tahmin edilmiştir. Bu çalışmada, yapılan yatırımın en fazla 2,5 yıl içerisinde geri döneceği ve mevcut yıllık üretim miktarının da yaklaşık 4 kat artacağı tespit edilmiştir.

Anahtar Kelimeler: Endüstriyel Otomasyon, PLC, Endüstriyel Robot, Diferansiyel Evrim Algoritması.

\footnotetext{
${ }^{*}$ This paper was produced from the master's thesis of the first author

${ }^{\dagger}$ Corresponding Author: enesefe@hitit.edu.tr
} 


\section{Avrupa Bilim ve Teknoloji Dergisi}

\section{Introduction}

As technology advances apace, new innovations have a critical effect on our lives. Manufacturing quality and the availability of cheap products have become inevitable necessities in today's global markets. The use of automation technologies has made it is possible to mass-produce items and lower production costs [1]. Automation is defined as the automatic control of a tool, process, or system as a result of observation, decision making, and the ability to effect changes via mechanical or electronic devices, rather than human interaction [2]. An entire task is shared by humans and machines, and the sharing ratio of this activity effectively determines the level of automation. If human power predominates, the resulting system is said to be semi-automated; if machine power is dominant, this is known as full automation [3]. Industrial automation (IA), which uses modern techniques and applications in manufacturing, is an impressive manufacturing strategy that leads to ongoing competition between rival companies [4]. These systems are capable of replacing human power in virtually any business sector and utilize vital control systems, such as programmable logic controllers (PLC), industrial robots, computers and information technologies. This strategy enables quality and flexibility to be increased within manufacturing operations, and, on inspecting the manufacturing processes of developed countries, it becomes immediately obvious when automation systems have been widely deployed.

Industrial robots, which are among the most critical elements of industrial automation systems, continue to grow in importance on a daily basis [5]. Japan was the first country to use robots in industry and, at the time, their introduction brought concerns that unemployment would rise. However, their widening usage has removed any doubts that this would happen and has, in fact, led to many new lines of work, with the result that unemployment has decreased substantially [6]. Today, they are most frequently used in working environments where there is a risk to human life from hazardous conditions, resulting from high temperatures, mechanical vibrations, chemicals, and nuclear energy [7].

The PLC is another important element of industrial automation systems. Intended to replace relay command circuits, the PLC was so named because it was only able to perform basic logic operations when first introduced. Firms such as Allen Bradley, General Electric, Siemens, and Westinghouse produced the first medium-cost and high-performance PLCs, allowing this type of controller to be applied in industry [3]. As Toshiba, Mitsubishi, and Omron developed low-cost, high-performance devices, their use in industrial automation systems became even more widespread [8]. PLCs have many attributes including, but not limited to, flexibility, reliability, ease of expansion, and low power consumption. It is possible to control alterations and enlarge the system solely by changing the PLC software [9].

Various industrial automation studies have been documented in which PLCs and industrial robots have been used. In 2007, Niola et. al. examined the possibility of using a video system to plan a robot's trajectory, and this was achieved by controlling robots with a computer mouse from a personal computer (PC) monitor [10]. Dong and Kuang's 2013 study analyzed the communication signals between a Mitsubishi PLC and GlaxoSmithKline robot [11]. In 2017, Stückelmaier et al. presented a method of gradually increasing the trajectory accuracy of industrial robots and examined dynamic modeling, definition, and kinematic calibration [12]. Jeong et al. published a study, in 2017, that discussed the software architecture of an integrated PLC robot, which played a key role in industrial smart systems [13]. Chen and Dong conducted studies to increase the accuracy and efficiency of robotic engraving and examined the feasibility of developing engraving systems that are capable of carrying out tasks that were previously thought to be the preserve of computer numerical control (CNC) machines [14].

In developed countries, engineering services are usually billed on an hourly basis. However, this is not the case in developing countries, such as Turkey, where remittance usually occurs at monthly intervals. In addition, advanced robots are more expensive compared to basic machines, and this results in additional costs for developing countries. Consequently, developed countries are able to use high-end industrial robots, that do not require additional engineering services and are capable of using PLC software, rather than having to procure further control systems. However, installation costs can be lowered by the use of a basic robot operating in conjunction with a PLC, and a number of studies have been documented that focus on reducing this expenditure.

This study was conducted in an active and physicallyaccommodating plant and produced statistical data, which was subsequently evaluated. In order to accurately calculate the cost of the installed system and determine the payback period, it was necessary to establish the price of the total electrical energy that the system would expend. This was determined by the use of a differential evolution (DE) algorithm to successfully predict future unit electricity prices, thereby allowing the total electricity bill for the system to be calculated. The DE algorithm is suitable for a range of applications in the electrical energy sector and can, for example, be used to determine load estimates, which are a crucial consideration in this field. Eke successfully estimated medium-term load using the DE algorithm [15], and Wang et al. used the DE algorithm to predict electrical energy consumption [16].

This study evaluated an automation system, consisting of an industrial robot and PLC, which was installed in a factory that manufactures side coupling globe valves (SCGV). The findings from this exercise were assessed and the costs of the system were compared with those that were incurred prior to installation. One of the most important aspects of this new system was the PLC, which, in combination with the industrial robot, enabled fast production. In addition, this study allowed the introduction of new techniques to calculate costs and determine the payback period.

This paper is structured as follows: Sections 2 are concerned with the installation of the industrial automation system and application of the proposed method; and Section 3-4 examines the experimental results which were obtained for the installed system.

\section{Material and Method}

This study focused on the use of an industrial automation system for the manufacture of valves with side couplings. Two CNC machines, a 6-axis industrial robot, and a PLC were provided for this purpose, and communications between these elements were achieved by the use of digital input-output signals. 


\subsection{Industrial Robot and PLC}

An industrial robot is defined, according to ISO 8373, as a manipulator with three or more axes, which is programmable, multipurpose, and can be either wheeled or stationary [17]. The mobility of this manipulator varies according to its number of axes and features, and electrical, hydraulic, or pneumatic driver systems are used to power its joint movements. An industrial robot essentially comprises the manipulator, a teach pendant, and controller, while elements that remain outside the system boundaries of the robot are termed peripherals. The end effector, in this case, a standard pneumatic gripper, is used to grab the working parts (Figure 1). Other peripherals include sensors, machines, conveyor belts, and security equipment, etc. The controller ensures that the industrial robot works in harmony with the peripheral devices and performs the desired movements [18].

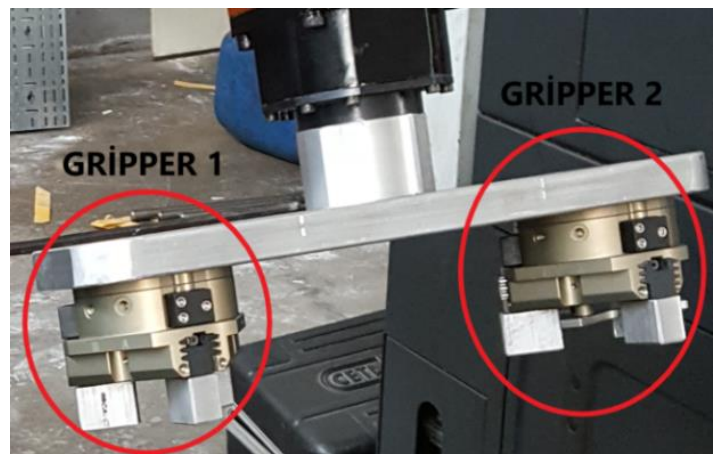

Fig. 1 The Standard Pneumatic Gripper Used as an End Effector in this Study.

PLCs have a microprocessor base, receive information from detectors in the field, and process this information as instructed. Consequently, they are able to control remote instrumentation and can be used in industrial automation systems to execute command and control mechanisms. In addition, PLCs are industrial computers that are equipped with input and output capabilities that enable them to communicate with separate devices and work in combination with SCADA [19]. The PLC examined in this study allowed the actions of the industrial robot and $\mathrm{CNC}$ to be synchronized, thereby allowing control of the hardware elements in the system.

\subsection{DE Algorithm}

The DE Algorithm was proposed by Storn and Price in 1995 and is a population-based method that uses operators resembling those in genetic instructions, such as mutation, selection, and crossing [20]. The DE Algorithm uses the following parameters: population size $(\mathrm{Np})$, scaling factor $(\mathrm{F})$, and crossing ratio $(\mathrm{Cr})$. The principal steps of the DE Algorithm are:

Step 1: Determination of the initial population.

Step 2: Evaluation of the initial population.

Step 3: Mutation.

Mutation is a process that adds the scaled difference of two random individuals to another individual that has been randomly selected from the population.

$$
v_{m, t+1}=x_{r_{3}, t}+F \times\left(x_{r_{1}, t}-x_{r_{2}, t}\right)
$$

In Equation 1, $v_{m, t+1}$ represents the mutated individual, while $x_{r_{1}, t}, x_{r_{2}, t}$, and $x_{r_{3}, t}$ are randomly selected individuals from the population $x_{r_{1}} \neq x_{r_{2}} \neq x_{r_{3}} \neq x_{i}$ ).

\section{Step 4: Crossing.}

The value of $C_{r}$ determines which genes are taken from the new individual, due to the mutation. If a randomly-generated value between 0 and 1 is less than $C_{r}$, it is chosen from $n_{j, i, G+1}$; if it is greater than C_r, it is selected from the current vector. The aim of these operations is to ensure that a previously specified ratio of genes are taken from the mutated individual. The mathematical expression for the crossing method is:

$$
x_{j, u, t+1}= \begin{cases}x_{j, m, t+1} & \text { if rand }[0,1] \leq C_{r} \text { or } j=j_{\text {rand }} \\ x_{j, i, t} \quad \text { otherwise }\end{cases}
$$

In Equation 2, $\mathrm{x}_{\mathrm{u}, \mathrm{t}+1}$ represents the candidate individual after crossing, and $\mathrm{j}$ is the current gene index. If none of the values acquired for any gene are less than $C_{r}$, the current individual remains unchanged. In order to circumvent this situation, a randomly-selected gene $\left(\mathrm{j}_{\text {rand }}\right)$ is updated to ensure at least one gene mutation occurs.

\section{Step 5: Choice.}

A choice is made in favor of the candidate individual or current individual that best fits the criteria. This practice is generally known as the greedy-choice method. A comparison is made between the current individual's purpose function performance and the candidate's solution.

\section{Step 6: Stopping Criterion.}

Steps 3, 4, and 5 are repeated sequentially until the stopping criterion is satisfied. Otherwise, the best solution is reported and the algorithm terminates.

\subsection{Installation of the Industrial Automation System}

The components of the industrial automation system installed during this study are shown in Figure 2. The system comprised two CNC machines, a handling station, an industrial robot, and PLC. The CNC machines were positioned directly opposite each other, with the robot installed between them, and the handling station was placed in front of the robot. The PLC controlled the hardware elements of the system and was in constant communication with the industrial robot. In addition to ensuring that the industrial robot and the CNCs worked in synchronization, the PLC controlled the operation of the handling station, while the industrial robot commanded the $\mathrm{CNC}$ machines. A program was written and uploaded to the PLC, in order to execute the necessary control operations.

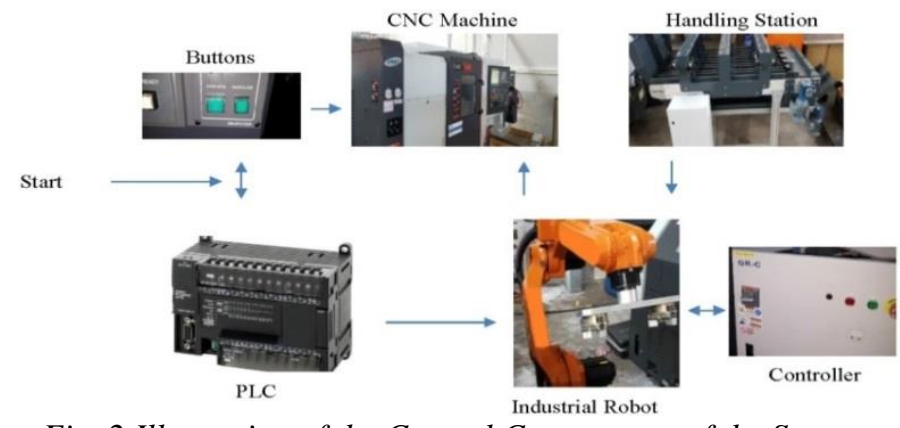

Fig. 2 Illustration of the Control Components of the System.

Two grippers were used to exchange processed and unprocessed parts. The first gripper carried the completed SCGV 
away from the $\mathrm{CNC}$, while the second gripper transported the unprocessed part to the CNC (Figure 3).

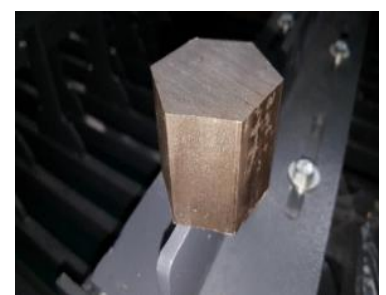

(a) Unprocessed Part.

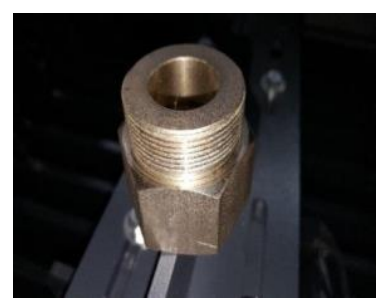

(b) Processed Part. Fig. 3

Having selected appropriate grippers, it was necessary to design a handling station that was suitable for use with the robot arm. Processed parts were carried to the conveyor by the robot.

The exchange of parts between the handling station and industrial robot was made possible by the use of optical proximity sensors, which were keyed at a frequency of $1000 \mathrm{~Hz}$. When the part had been completed, the sensors sent a ready signal to the robot, which seized it using the gripper. Figure 4 depicts the position of the sensors on the handling station, while Figure 5 shows the use of the gripper to seize a part.

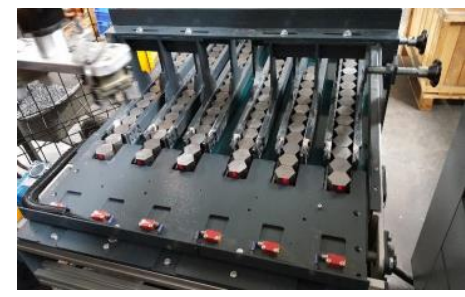

Figure 4. Handling Station Sensors.

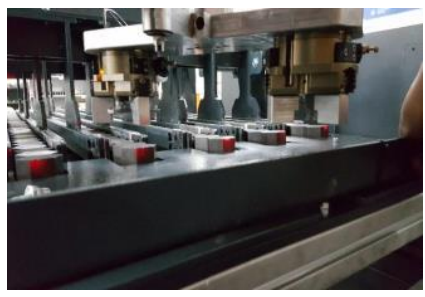

Figure 5. Gripper Receiving a Part.
In order to ensure that the actions of the handling station and CNC machines were coordinated, it was necessary to use a PLC with a sufficient number of inputs and outputs. The PLC was required to control the handling station, $\mathrm{CNC}$ gates, and mirrors, and the manufacturer's proprietary ladder programming language was used to ensure this functionality was satisfied. In addition to being operated via the industrial robot, the $\mathrm{CNC}$ machine gates and mirrors were also controlled by the PLC. Manual operation was therefore possible when the industrial robot was switched off. When the system starts up, the industrial robot initially takes the unprocessed part from the handling station (Figure 6 (a)) and then hands it to the $\mathrm{CNC}$ for processing, while simultaneously taking the completed part away from the machine (Figure 6 (b) (c)). Lastly, the robot places the processed part on the conveyor.

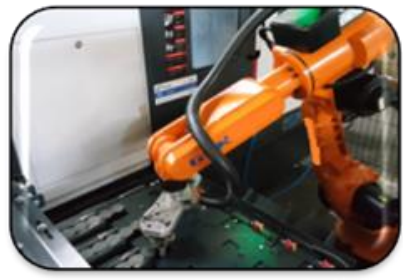

(a)

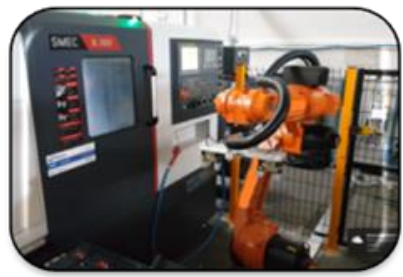

(b)

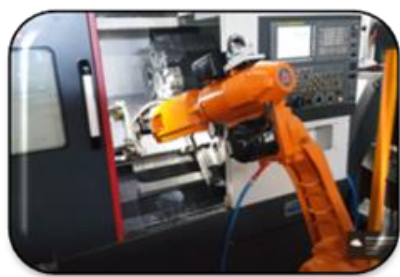

(c)

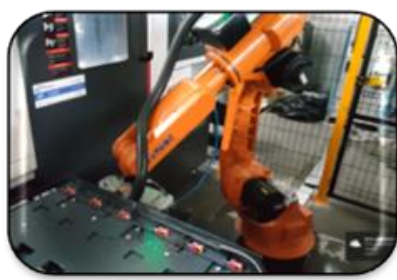

(d)
Fig. 6 Industrial Robot Actions.

Control of the CNC machine's gates was switched from manual to automatic using dual pneumatic valves, a 40 x $40 \mathrm{x}$ $600 \mathrm{~mm}$ piston, and magnetic sensors, which operated at a switching frequency of $5000 \mathrm{~Hz}$ (Figure 7).

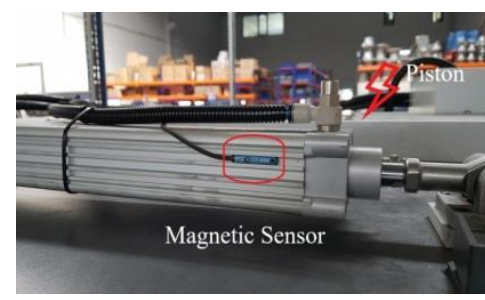

(a)

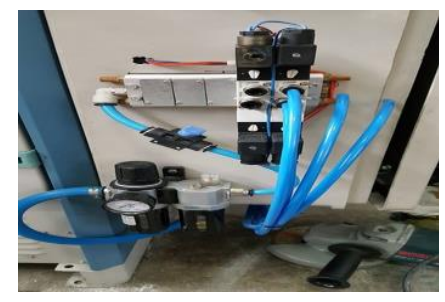

(b)
Fig. 7 (a) Piston. (b) Dual Pneumatic Valve.

Finally the industrial robot was programmed with its integrated programming language, which resembled $\mathrm{C}$, to ensure system stability.

\subsection{Electricity Price Prediction Using the DE Algorithm}

In order to observe the system's efficiency and determine the payback period, it was necessary to estimate the unit price of electricity in the following years. Since electricity prices depend on a multitude of parameters, they can be highly variable over a period of time. It was therefore necessary to adopt the use of robust and reliable methods, through the use of smart systems, to provide suitable forecasts. Although there are no documented studies concerning the calculation of unit electricity prices, numerous enquiries have been carried out into the estimation of future energy demand. Many nature-inspired algorithms have been used for this purpose and these include a number of computational methods, such as the genetic algorithm [21, 22], particle swarm optimization [23, 24], ant colony optimization [25], artificial bee colony optimization [26], the DE algorithm [27], and various hybrid techniques [28]. Studies have also been undertaken with regard to the estimation of electricity generation and consumption [29-31]. This study adopted the use of the DE algorithm, which, in addition to offering efficient performance and being easy to apply, was based on the work of Beskirli et al. [27], who proposed its use for energy demand estimation in preference to other nature-inspired methods.

Four economic criteria were considered when estimating energy demand: gross domestic product (GDP), population, and values of imports and exports. [23-27]. These parameters, together with electricity generation and consumption, directly influence unit electricity prices. Table 1 contains values for these 6 criteria between 1995 and 2015 [29]. 
European Journal of Science and Technology

Table 1. Unit electricity price ( $k W h), G D P$, population, values of imports and exports, electricity production and electricity consumption for Turkey between 1995 and 2015.

Name and number of variables

\begin{tabular}{|c|c|c|c|c|c|}
\hline \multicolumn{6}{|c|}{ Name and number of variables } \\
\hline 1 & 2 & 3 & 4 & 5 & 6 \\
\hline $\begin{array}{r}\text { GDP } \\
\left(\$ 10^{\wedge} 9\right)\end{array}$ & $\begin{array}{l}\text { Population } \\
\left(10^{\wedge} 6\right)\end{array}$ & $\begin{array}{l}\text { Import } \\
\left(\$ 10^{\wedge} 9\right)\end{array}$ & $\begin{array}{c}\text { Export } \\
\left(\$ 10^{\wedge} 9\right)\end{array}$ & $\begin{array}{c}\text { Electricity } \\
\text { production } \\
\left(\mathbf{1 0}^{\wedge} 9\right)\end{array}$ & $\begin{array}{c}\begin{array}{c}\text { Electricity } \\
\text { consumption } \\
\left(\mathbf{1 0}^{\wedge} 9\right)\end{array} \\
\end{array}$ \\
\hline 168.08 & 58.48 & 35.71 & 21.64 & 86.25 & 67.39 \\
\hline 181.07 & 59.42 & 43.63 & 23.22 & 94.86 & 74.16 \\
\hline 188.73 & 60.37 & 48.56 & 26.26 & 103.30 & 81.89 \\
\hline 270.94 & 61.32 & 45.92 & 26.97 & 111.02 & 87.71 \\
\hline 247.54 & 62.28 & 40.67 & 26.59 & 116.44 & 91.20 \\
\hline 265.38 & 63.24 & 54.50 & 27.78 & 124.92 & 98.30 \\
\hline 196.73 & 64.19 & 41.40 & 31.33 & 122.73 & 97.07 \\
\hline 230.49 & 65.14 & 51.55 & 36.06 & 129.40 & 102.95 \\
\hline 304.90 & 66.08 & 69.34 & 47.25 & 140.58 & 111.77 \\
\hline 390.38 & 67.00 & 97.54 & 63.17 & 150.70 & 121.14 \\
\hline 481.49 & 67.90 & 116.77 & 73.48 & 161.96 & 130.26 \\
\hline 526.42 & 68.76 & 139.58 & 85.54 & 176.30 & 143.07 \\
\hline 648.75 & 69.59 & 170.06 & 107.27 & 191.56 & 155.14 \\
\hline 742.09 & 70.44 & 201.96 & 132.03 & 198.42 & 161.95 \\
\hline 616.70 & 71.33 & 140.93 & 102.14 & 194.81 & 156.89 \\
\hline 731.60 & 72.32 & 185.54 & 113.88 & 211.21 & 172.05 \\
\hline 773.97 & 73.40 & 240.84 & 134.91 & 229.40 & 186.10 \\
\hline 786.28 & 74.56 & 236.54 & 152.47 & 239.50 & 194.92 \\
\hline 823.04 & 75.78 & 251.66 & 151.81 & 240.15 & 198.05 \\
\hline 799.36 & 77.03 & 242.17 & 157.62 & 251.96 & 207.38 \\
\hline 719.62 & 78.27 & 207.23 & 143.84 & 261.78 & 217.31 \\
\hline
\end{tabular}

Examination of Table 1 indicates that, although electricity generation and consumption have steadily increased over the years, there are periods of time when electricity unit prices have stayed relatively constant, or even slightly declined, prior to subsequent increases. In general, GDP and the values of imports have risen steadily between 1995 and 2013, although they have fallen in the last two years of the period considered.

Two separate models, one linear, the other quadratic, were implemented to estimate energy or electricity demand [23, 2527]. Of these, the quadratic model proved to be much more efficient and was preferred for this study. The quadratic equation for four variables can be expressed as follows:

$$
E_{\text {quadratic }}=w_{1}+w_{2} X_{1}+w_{3} X_{2}+w_{4} X_{3}+w_{5} X_{4}+
$$$$
w_{6} X_{1} X_{2}+w_{7} X_{1} X_{3}+w_{8} X_{1} X_{4}+w_{9} X_{2} X_{3}+w_{10} X_{2} X_{4}+
$$$$
w_{11} X_{3} X_{4}+w_{12} X_{1}^{2}+w_{13} X_{2}^{2}+w_{14} X_{3}^{2}+w_{15} X_{4}^{2}
$$

The parameters $X_{1}, X_{2}, X_{3}, X_{4}$ represent GDP, population, values of imports, and values of exports, respectively, while $w_{1}$, $w_{15}$ are their corresponding weights. Equation 3 is formulated for 4 variables, and if this number increases, the formula must be changed accordingly. For 4 variables, there are 15 weights (also the dimensions of the problem); when there are 5 variables there are 21 weights; and 6 variables require 28 weights. The accuracy of the prediction is verified by the purpose function shown in Equation 4.

$$
\min f(v)=\sum_{r=1}^{R}\left(E_{r}^{\text {observed }}-E_{r}^{\text {predicted }}\right)^{2}
$$

$E_{r}^{\text {observed }}$ and $E_{r}^{\text {predicted }}$ are the observed and predicted unit electricity prices, respectively, and $\mathrm{R}$ is the year in which the observation occurs. The main objective is to find the weights which correspond to the $\min f(v)$ value for each year [27]. The smaller $f(v)$ is, the more accurate the estimate for a given year is.

\section{Results}

In this study, experimental testing was carried out using a PC equipped with an i5-6400 central processing unit (CPU), an AMD Radeon R7-200 graphics processing unit (GPU), and 8 gigabytes (GB) of random-access memory (RAM). The Industrial Automation System was realized in firm facilities. The experimental results were separated into three parts; an 
evaluation of the utility of the system, unit electricity price estimates, and cost analysis and payback period calculations.

\subsection{Analysis of the Industrial Automation System Output}

A significant increase in production was noted after the industrial robot and PLC had been installed. Prior to automation, the daily production output, between 8 a.m. and 6 p.m., was an average of 400 units, while after installation the output had risen to an average quantity of 585 units. If the system was allowed to run round the clock, this output jumped to around 1400 units. Previously, daily production was limited to approximately 8 hours, after the workers' lunch breaks and recess times had been taken into account. Following automation, continuous production was possible on a 24-hour basis, and this was the most significant benefit to result from installation of the system.

The system provides an additional advantage in that the PLC can allow manual production, if required. Machining is only possible with the use of the industrial robot; however, manual production is only possible if the PLC and robot are active.

\subsection{Future Projections of Unit Electricity Price}

The data presented in Table 1, over a 21 year period, was used for the estimation of electricity unit prices, using the DE algorithm. In this analysis, $\mathrm{F}$ was taken to be 0.5 , while $\mathrm{Cr}$ and $\mathrm{Np}$ were set to values of 0.9 and 100, respectively. The maximum number of function evaluations was specified as $5 \times 105$. The variables GDP, population, and values of imports and exports were initially tested as stand-alone criteria; electricity generation and consumption were then tested in combination with the other parameters (Table 2). The quadratic form given in Equation 3 was rearranged in accordance with the number of variables used.

The DE algorithm was run using variables that were chosen for 4 different scenarios, and, after 10 trials, the best results were selected for use in this study. Table 2 gives the weights and errors for the 4 variables used.
Table 2. Comparisons of Coefficients and Relative Errors.

\begin{tabular}{|c|c|c|c|c|}
\hline \multirow[b]{2}{*}{ Coefficients } & \multicolumn{4}{|c|}{ Selected Variables } \\
\hline & $1,2,3,4$ & $1,2,3,4,5$ & $1,2,3,4,6$ & $1,2,3,4,5,6$ \\
\hline w1 & 10.00000 & -9.17532 & 9.62941 & -8.48483 \\
\hline w2 & -0.24023 & 0.09704 & 3.32920 & -2.61183 \\
\hline w3 & -1.29403 & -9.99305 & 1.60644 & 9.02448 \\
\hline w4 & -3.00539 & 2.19926 & -4.12544 & -8.70575 \\
\hline w5 & 6.02331 & -4.09795 & -6.21791 & -1.76599 \\
\hline w6 & 0.00453 & 3.31954 & -6.13156 & 9.94205 \\
\hline w7 & 0.00122 & -0.00483 & -0.08804 & -7.33863 \\
\hline w8 & 0.00204 & -0.01348 & -0.00783 & -0.01581 \\
\hline w9 & 0.04775 & 0.00536 & -0.02306 & -0.03232 \\
\hline w10 & -0.09946 & -0.00096 & 0.02342 & 0.21898 \\
\hline w11 & -0.00991 & -0.03412 & 0.15556 & 0.49497 \\
\hline w12 & -0.00041 & 0.14561 & 0.20481 & -0.54486 \\
\hline w13 & 0.01937 & -0.15470 & 0.04591 & -0.29004 \\
\hline w14 & -0.00037 & 0.06002 & 0.04389 & 0.43933 \\
\hline w15 & 0.00681 & 0.01262 & -0.07044 & 1.65158 \\
\hline w16 & - & -0.05923 & -0.05802 & -1.34516 \\
\hline w17 & - & 0.00168 & 0.00228 & 0.58050 \\
\hline w18 & - & 0.24909 & 0.01065 & 1.91664 \\
\hline w19 & - & -0.00033 & 0.01433 & -2.07848 \\
\hline w20 & - & -0.03886 & 0.03802 & -2.73528 \\
\hline w21 & - & 0.03174 & 0.01783 & 2.86035 \\
\hline w22 & - & - & - & -1.90207 \\
\hline w23 & - & - & - & -0.01904 \\
\hline w24 & - & - & - & -0.55196 \\
\hline w25 & - & - & - & -0.17802 \\
\hline w26 & - & - & - & -0.85209 \\
\hline w27 & - & - & - & -0.38560 \\
\hline w28 & - & - & - & 2.64912 \\
\hline Error Rate & 33.21 & 9.79 & 21.83 & 3016.10 \\
\hline
\end{tabular}

Examination of Table 2 reveals that the best electric unit price estimation, with a 9.79 error rate, resulted from the combination of variables $1,2,3,4$, and 5 . When electricity generation and consumption were both included in the calculations, the error rate for the estimate became significantly higher in relation to other conditions. Incremental increases in the error value corresponded to higher fitting values, which are the product of a square function [27]. Future projections relied on the combination of GDP, population, values of imports, and values of exports.

Figure 8 compares the estimates obtained for variables 1, 2, 3, 4, and 5, with the values observed between 1995 and 2015. The results show that, in general, the estimations were very close to the actual values, and it can be concluded that the proposed model was reliable and fit for purpose. This is particularly true when examining the findings for 2000, 2007, and 2009; although some disparity is evident for 2002 and 2003. 


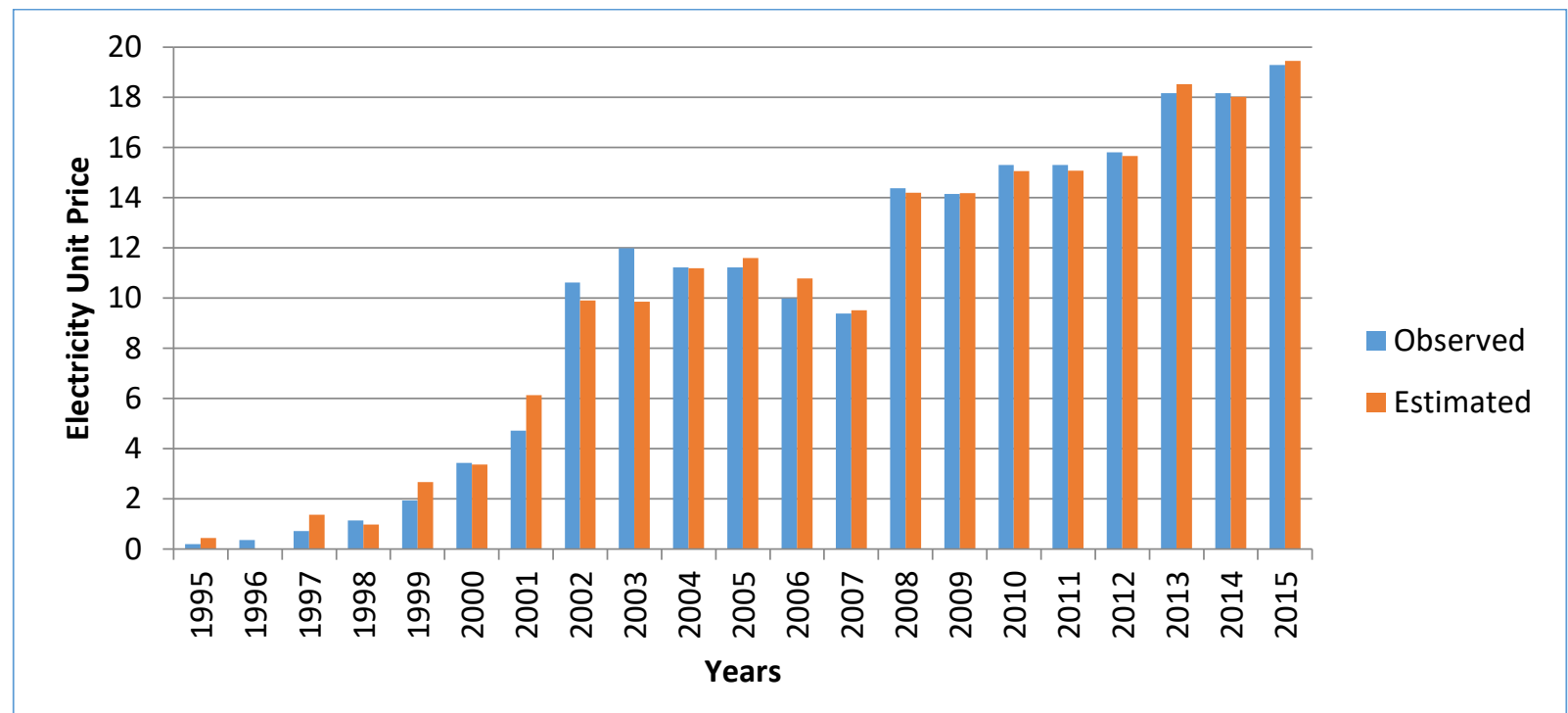

Comparison of Observed and Estimated Electricity Unit Prices.

Fig. 8

Three different scenarios were prepared for the estimation of electricity unit prices in Turkey, between 2016 and 2035.

Scenario 1: Between 2016-2035, the following were assumed: a mean GDP growth rate of $3 \%$, a population growth rate of $1 \%$, an import growth rate of $3 \%$, and a $5 \%$ increase in electricity production and values of exports.

Scenario 2: Between 2016-2035, the following were assumed: a mean GDP growth rate of $4 \%$, a population growth rate of $2 \%$, an import growth rate of $4 \%$, and a $5 \%$ increase in electricity production and values of exports.

Scenario 3: Between 2016-2035, the following were assumed: a mean GDP growth rate of $6 \%$, a population growth rate of $4 \%$, an import growth rate of $6 \%$, and a $7 \%$ increase in electricity production and values of exports. Table 3 contains future projections that were obtained for each scenario, using the weight values acquired from the DE algorithm. These scenarios were determined by considering low, normal, and high levels of increase in the appropriate variables. Examination of the findings reveals that Scenario 1 resulted in the highest level of agreement between the estimations and actual figures, from 2016 to 2018. The rapid increase in unit price observed for Scenario 2 and less inflationary trends of Scenarios 1 and 3 are illustrated in Figure 9. It can be seen that after 2022, the estimates obtained for Scenario 3 were initially smaller than those of the other data sets; after 2030, however, they quickly increased and went on to exceed the values derived for Scenario 1. The results show that the estimated figures for Scenarios 2 and 3 continued to increase over time, while the values obtained for Scenario 1 fell over the last two years of the time frame.

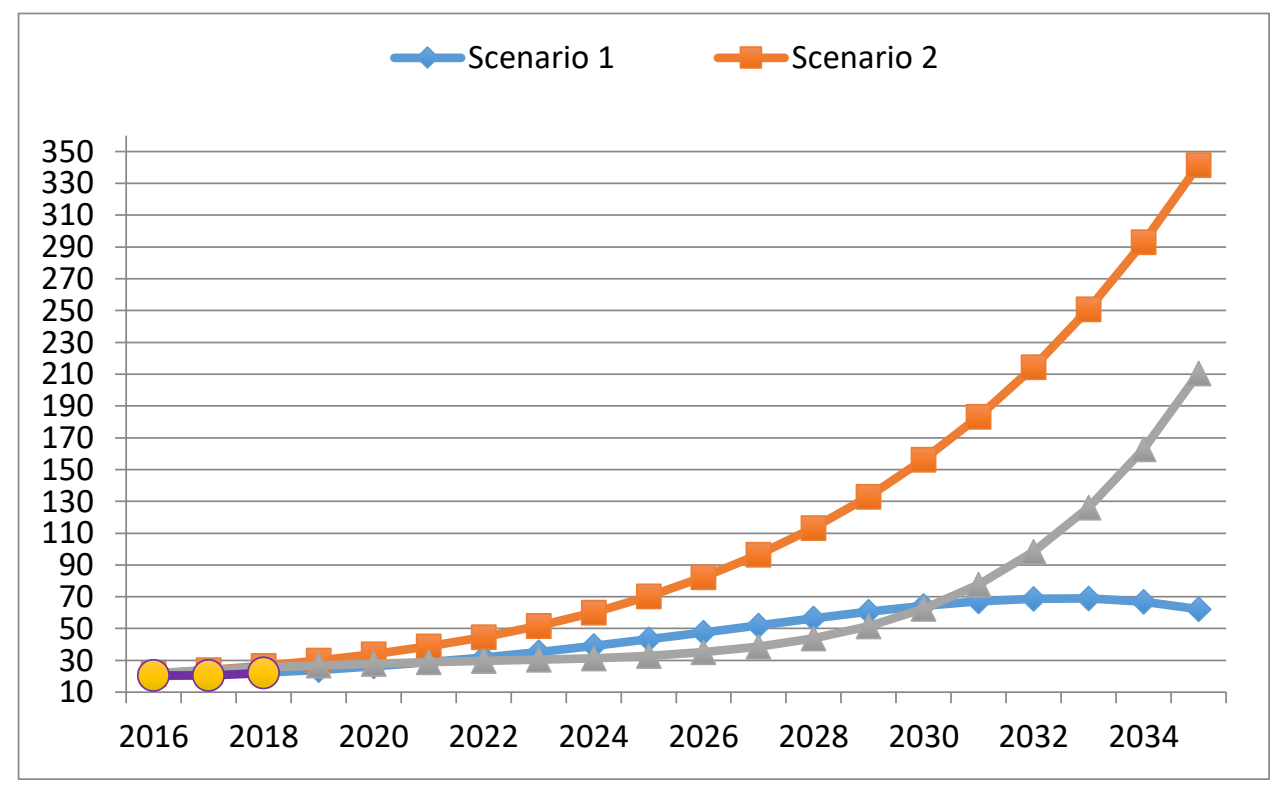

Fig. 9 Future Projections of Electricity Unit Price for Scenarios 1-3. 


\subsection{Systems Costs and Profit Analysis}

Future projections of the electricity unit price were used to carry out a cost and profit analysis, and the following tariffs were added to these values: a $40 \%$ distribution charge for unilateral industry groups, a $1 \%$ energy fund, a $5 \%$ municipal consumption $\operatorname{tax}(\mathrm{MCT})$, and $18 \%$ value added tax (VAT). Table 3 shows the resulting estimates for all three scenarios.

Table 3. Electricity Prices Estimates Including Tax (Turkish kurus).

\begin{tabular}{cccc}
\multicolumn{3}{c}{ Scenarios } \\
\hline Year & $\mathbf{1}$ & $\mathbf{2}$ & $\mathbf{3}$ \\
\hline 2019 & 39.36 & 64.54 & 105.85 \\
2020 & 42.94 & 70.42 & 115.49 \\
2021 & 47.23 & 77.46 & 127.04 \\
2022 & 52.23 & 85.66 & 140.48 \\
2023 & 57.89 & 94.93 & 155.69 \\
2024 & 64.14 & 105.19 & 172.52 \\
2025 & 70.89 & 116.27 & 190.68 \\
2026 & 78.00 & 127.93 & 209.80 \\
2027 & 85.28 & 139.86 & 229.37 \\
2028 & 92.48 & 151.67 & 248.73 \\
2029 & 99.28 & 162.83 & 267.04 \\
2030 & 105.30 & 172.69 & 283.21 \\
2031 & 110.04 & 180.46 & 295.95 \\
2032 & 112.89 & 185.14 & 303.64 \\
2033 & 113.14 & 185.56 & 304.31 \\
2034 & 109.92 & 180.26 & 295.63 \\
2035 & 102.16 & 167.54 & 274.76 \\
\hline
\end{tabular}

Two different modes of operation were examined during this study. In the first of these (Mode a), it was assumed that the new system would work continuously for 24 hours; in the second mode (Mode b), it was assumed that work would only take place between the hours of 8 a.m. and 6 p.m. The total energy costs of the system were calculated for both operating modes, using the previous cost estimates with taxes (Table 4). In addition, the ticket prices of the control elements of the system were included, and the average power consumption of these components was taken as $5.5 \mathrm{~kW}$ and multiplied by the electricity prices including tax. The total number of working days was assumed to be 260, allowing for weekends, and the results were multiplied by this figure in order to calculate the annual energy costs of the system.
Table 4. Total Energy Costs of the System for Various Scenarios and Operating Modes $\left(10^{3}\right.$ Turkish lira).

\begin{tabular}{|c|c|c|c|c|c|c|}
\hline \multirow[b]{3}{*}{ Year } & \multicolumn{6}{|c|}{ Scenarios/ Operating Modes } \\
\hline & \multicolumn{2}{|c|}{1} & \multicolumn{2}{|c|}{2} & \multicolumn{2}{|c|}{3} \\
\hline & $\mathbf{a}$ & b & $\mathbf{a}$ & b & a & b \\
\hline 2019 & 13.51 & 5.63 & 22.15 & 9.23 & 36.33 & 15.14 \\
\hline 2020 & 14.74 & 6.14 & 24.17 & 10.07 & 39.63 & 16.51 \\
\hline 2021 & 16.21 & 6.75 & 26.59 & 11.08 & 43.60 & 18.17 \\
\hline 2022 & 17.93 & 7.47 & 29.40 & 12.25 & 48.21 & 20.09 \\
\hline 2023 & 19.87 & 8.28 & 32.58 & 13.58 & 53.43 & 22.26 \\
\hline 2024 & 22.01 & 9.17 & 36.10 & 15.04 & 59.21 & 24.67 \\
\hline 2025 & 24.33 & 10.14 & 39.90 & 16.63 & 65.44 & 27.27 \\
\hline 2026 & 26.77 & 11.15 & 43.90 & 18.29 & 72.00 & 30.00 \\
\hline 2027 & 29.27 & 12.20 & 48.00 & 20.00 & 78.72 & 32.80 \\
\hline 2028 & 31.74 & 13.22 & 52.05 & 21.69 & 85.37 & 35.57 \\
\hline 2029 & 34.07 & 14.20 & 55.88 & 23.28 & 91.65 & 38.19 \\
\hline 2030 & 36.14 & 15.06 & 59.27 & 24.69 & 97.20 & 40.50 \\
\hline 2031 & 37.76 & 15.74 & 61.93 & 25.81 & 101.57 & 42.32 \\
\hline 2032 & 38.74 & 16.14 & 63.54 & 26.48 & 104.21 & 43.42 \\
\hline 2033 & 38.83 & 16.18 & 63.68 & 26.53 & 104.44 & 43.52 \\
\hline 2034 & 37.72 & 15.72 & 61.87 & 25.78 & 101.46 & 42.27 \\
\hline 2035 & 35.06 & 14.61 & 57.50 & 23.96 & 94.30 & 39.29 \\
\hline
\end{tabular}

It was assumed that workers would be paid the minimum wage. Since accurate forecasts for the inflation rate were critical for reliable estimates, appropriate data was obtained from the Central Bank of Turkey. After installation, labor costs were largely replaced by the energy costs of the system, and the difference between them was multiplied by 260 to give the profits shown.

The price increases for SCGVs were determined in accordance with the inflation rate forecasts. SCGV unit prices were multiplied by the average daily production figure of 400 and number of working days (260) to obtain the annual income prior to installation. The corresponding revenue after installation was calculated in a similar fashion, and daily production estimates of 1400 and 585 units were assumed for Modes a and b, respectively.

Table 5 presents the cumulative total profit for each scenario and operating mode over the period in question. It should be noted that the manufacturer paid an initial system installation cost of 42,000 euros. 


\begin{tabular}{|c|c|c|c|c|c|c|}
\hline \multirow[b]{3}{*}{ Years } & \multicolumn{6}{|c|}{ Scenarios } \\
\hline & \multicolumn{2}{|c|}{1} & \multicolumn{2}{|c|}{2} & \multicolumn{2}{|c|}{3} \\
\hline & $\mathbf{a}$ & b & $\mathbf{a}$ & b & $\mathbf{a}$ & b \\
\hline 2019 & 403.40 & 93.43 & 394.75 & 89.82 & 380.57 & 83.92 \\
\hline 2020 & 847.03 & 196.02 & 828.96 & 188.49 & 799.31 & 176.14 \\
\hline 2021 & 1334.62 & 308.47 & 1306.17 & 296.61 & 1259.51 & 277.17 \\
\hline 2022 & 1870.22 & 431.47 & 1830.30 & 414.83 & 1764.83 & 387.55 \\
\hline 2023 & 2458.33 & 565.80 & 2405.70 & 543.87 & 2319.37 & 507.90 \\
\hline 2024 & 3104.08 & 712.50 & 3037.36 & 684.69 & 2927.93 & 639.10 \\
\hline 2025 & 3813.16 & 872.67 & 3730.86 & 838.38 & 3595.89 & 782.14 \\
\hline 2026 & 4591.86 & 1047.59 & 4492.43 & 1006.16 & 4329.36 & 938.22 \\
\hline 2027 & 5447.20 & 1238.67 & 5329.04 & 1189.43 & 5135.25 & 1108.69 \\
\hline 2028 & 6386.96 & 1447.47 & 6248.49 & 1389.77 & 6021.39 & 1295.15 \\
\hline 2029 & 7419.85 & 1675.81 & 7259.57 & 1609.03 & 6996.71 & 1499.50 \\
\hline 2030 & 8555.56 & 1925.74 & 8372.15 & 1849.32 & 8071.35 & 1723.99 \\
\hline 2031 & 9804.89 & 2199.54 & 9597.31 & 2113.05 & 9256.87 & 1971.20 \\
\hline 2032 & 11179.85 & 2499.80 & 10947.47 & 2402.98 & 10566.37 & 2244.19 \\
\hline 2033 & 12693.86 & 2829.43 & 12436.62 & 2722.25 & 12014.77 & 2546.47 \\
\hline 2034 & 14361.85 & 3191.69 & 14080.47 & 3074.45 & 13619.02 & 2882.17 \\
\hline 2035 & 16200.49 & 3590.27 & 15896.68 & 3463.68 & 15398.43 & 3256.08 \\
\hline
\end{tabular}

Initial installation cost was 42,000 euros (222,306 TL, according to exchange rate of 01.06.18).

Figure 10 shows the profit graphs for the scenarios and operating modes in question. It can be seen that if the automated system commenced operation in 2019, it would become profitable within 2-3 years, assuming 8 a.m. to 6 p.m. working. However, if the system was operated on a 24 hour basis, it would become profitable within the first year. Although theoretically possible, producers prefer to avoid continuous production due to the attendant reduction in machine service life.

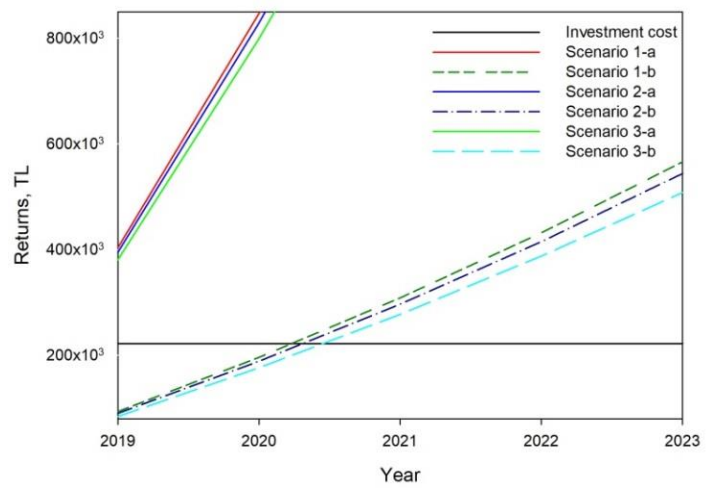

Fig. 10 Profit Graph of the System.

\section{Discussion and Conclusion}

This study considered the installation of an industrial automation system which produced SCGVs. One of the innovations that were done in this study is that the Industrial Automation System computes the time to return to profitability by using artificial intelligence techniques. In contrast to many other systems, a PLC was used in addition to an industrial robot and, in order to accurately calculate the costs of the installed system to the producer, a DE algorithm was used to estimate future electricity unit prices in Turkey. Thus the total energy cost was calculated and compared with the labor costs prior to installation. In the light of this study, the system was expected to become profitable within 2.5 years and return considerable gains thereafter.

The use of a PLC provides significant advantages, namely: the ability of the system to operate manually, providing continuous production, and the option to procure cheaper robots without additional features. Furthermore, the resulting simplicity of the robot software increases the usability of the system. In summary, the installation of this automated system resulted in increased production and higher levels of efficiency and flexibility.

In the future, it may be possible to achieve greater efficiency by reducing energy expenditure. The electric energy used by the system could be supplied from renewable energy sources, and the system could be made more economical. Moreover, the use of a wireless communication feature could increase the usability of the system by enabling control over a remote computer.

\section{References}

1. Yücel, İ.H., Sanayide Robot Teknolojisi. Uygulaması Ve Önemi, DPT Yayınları, Ankara, Aralık, 1991.

2. Sheridan, T.B., Telerobotics, automation, and human supervisory control. 1992: MIT press.

3. Özcan, M., Otomasyon sistemlerinde PLC uygulamalart. 2004: Atlas Yayın dağıtım. 


\section{Avrupa Bilim ve Teknoloji Dergisi}

4. Acharya, V., S.K. Sharma, and S. Kumar Gupta, Analyzing the factors in industrial automation using analytic hierarchy process. Computers \& Electrical Engineering, 2017.

5. Çengelci, B. and H. Çimen, Endüstriyel robotlar. Makine Teknolojileri Elektronik Dergisi, 2005. 2(2): p. 69-78.

6. Peşkircioğlu, N., Otomasyon ve Entegre Kalite Kontrolu. Verimlilik Dergisi, (15): p. 19-40.

7. De Silva, D., Reactions to Robots, Engineering. 1987, April.

8. Kurtulan, S., PLC ile endüstriyel otomasyon. 2001: Birsen Yayınevi.

9. Rehg, J.A. and G.J. Sartori, Programmable logic controllers. 2009, Upper Saddle River, N.J.: Pearson Prentice Hall.

10. Niola, V., C. Rossi, and S. Savino, Vision system for industrial robots path planning. International journal of Mechanics and control, 2007. 8(1): p. 35-45.

11. CHEN, D.-q. and Y.-c. KUANG, Communication between Mitsubishi PLC and GSK Industrial Robot. Mechanical Engineer, 2013. 4: p. 023.

12. Stückelmaier, P., M. Grotjahn, and C. Fräger. Iterative improvement of path accuracy of industrial robots using external measurements. in Advanced Intelligent Mechatronics (AIM), 2017 IEEE International Conference on. 2017. IEEE.

13. Jeong, H.S., et al. Design of $S W$ architecture for PLC integrated robot. in Ubiquitous Robots and Ambient Intelligence (URAI), 2017 14th International Conference on. 2017. IEEE.

14. Chen, Y. and F. Dong, Robot machining: recent development and future research issues. The International Journal of Advanced Manufacturing Technology, 2013. 66(9-12): p. 1489-1497.

15. Eke, İ., Diferansiyel evrim algoritması destekli yapay sinir ă̆ ile orta dönem yük tahmini. Uluslararası Mühendislik Araştırma ve Geliştirme Dergisi, 2011. 3(1): p. 28-32.

16. Wang, L., et al., Effective electricity energy consumption forecasting using echo state network improved by differential evolution algorithm. Energy, 2018. 153: p. 801815.

17. Standard, I., 8373: 1994. Manipulating industrial robotsVocabulary.

18. Dişlitaş, S., Endüstriyel Robot Programlama. Bask1, Endüstriyel Robot Programlama Eğitimi ile Mesleki ve Teknik Eğitim Güçlendirilmesi (ERPE-METEG) Projesi, Çorum, 2015.

19. Mirzaoğlu, İ. and M. Sarıtaş, PLC VE SCADA Kullanarak Bir Irmik Üretim Sisteminin Otomasyonu. 2008.

20. Storn, R. and K. Price, Differential evolution-A simple and efficient adaptive scheme for global optimization over continuous spaces [R]. Berkeley: ICSI, 1995.

21. Canyurt, O.E., et al., Energy demand estimation based on two-different genetic algorithm approaches. Energy Sources, 2004. 26(14): p. 1313-1320.

22. Ceylan, H. and H.K. Ozturk, Estimating energy demand of Turkey based on economic indicators using genetic algorithm approach. Energy Conversion and Management, 2004. 45(15-16): p. 2525-2537.

23. Unler, A., Improvement of energy demand forecasts using swarm intelligence: The case of Turkey with projections to 2025. Energy Policy, 2008. 36(6): p. 1937-1944.

24. Gulcu, S. and H. Kodaz, The estimation of the electricity energy demand using particle swarm optimization algorithm: A case study of Turkey. 8th International
Conference on Advances in Information Technology, 2017. 111: p. 64-70.

25. Toksari, M.D., Estimating the net electricity energy generation and demand using the ant colony optimization approach: Case of Turkey. Energy Policy, 2009. 37(3): p. 1181-1187.

26. Sonmez, M., A.P. Akgungor, and S. Bektas, Estimating transportation energy demand in Turkey using the artificial bee colony algorithm. Energy, 2017. 122: p. 301-310.

27. Beskirli, M., H. Hakli, and H. Kodaz, The energy demand estimation for Turkey using differential evolution algorithm. Sadhana-Academy Proceedings in Engineering Sciences, 2017. 42(10): p. 1705-1715.

28. Kiran, M.S., et al., A novel hybrid approach based on Particle Swarm Optimization and Ant Colony Algorithm to forecast energy demand of Turkey. Energy Conversion and Management, 2012. 53(1): p. 75-83.

29. Yumurtaci, Z. and E. Asmaz, Electric energy demand of Turkey for the year 2050. Energy Sources, 2004. 26(12): p. 1157-1164.

30. Kavaklioglu, K., et al., Modeling and prediction of Turkey's electricity consumption using Artificial Neural Networks. Energy Conversion and Management, 2009. 50(11): p. 27192727.

31. Toksari, M.D., A hybrid algorithm of Ant Colony Optimization (ACO) and Iterated Local Search (ILS) for estimating electricity domestic consumption: Case of Turkey. International Journal of Electrical Power \& Energy Systems, 2016. 78: p. 776-782. 